\title{
COPING WITH BIG CLASSES: EFFECT OF BIG BOOK IN FOURTH GRADE STUDENTS READING COMPREHENSION
}

\author{
Mahayanti, N.W.S. \\ English Language Education, Faculty of Language and Art \\ Ganesha University of Education \\ Singaraja, Indonesia \\ mahayantisurya@yahoo.co.id \\ Padmadewi, N.N. \\ English Language Education, Faculty of Language and Art \\ Ganesha University of Education \\ Singaraja, Indonesia \\ padmadewi@northbalibilingualschool.org
}

Wijayanti, L.P.A. English Language Education, Faculty of Language and Art Ganesha University of Education

Singaraja, Indonesia ayuwijaynti401@gmail.com

\begin{abstract}
Teaching reading comprehension for young learners becomes a challenge for English teachers in Indonesia. Dealing with that problem, this study had a purpose to investigate whether there was any significant effect on students' reading comprehension taught by using big book and conventional media or not. Post-test only control group was used as the design with forth grade students of SD Laboratorium Undiksha Singaraja as the population. The data were analyzed descriptively and inferentially. As the result, it can be concluded that big book gives significant effect on students reading comprehension compared with the control group. It can be proven from the difference of mean score gained by experimental group (83.56) and control group (76.19). The result of the t-test also shows that the t-observed exceeded the t-critical value $(4.088>2.042)$.
\end{abstract}

Key words: big book, reading comprehension, young learner.

\section{INTRODUCTION}

Reading is one of the important skills in that a person can possibly acquire. By mastering reading skill students are able to learn something from what they read so they, gain useful new information and knowledge for their future (Grabe, 2009). Reading is a lifelong skill because this skill can be used not only at school or throughout life but you may use this skill for both of them. Reading is a process that is done and used by readers to get the author's messageTarigan(2008) in Givanda (2013). Through the written text, writer tries to transfer the information that the writer has to the reader and it can enrich the knowledge or the information of the reader. Reading is a crucial skill in learning and communication and current trend in education emphasize the importance of reading lessons as an important early step in the development mental and linguistic abilities" (Alshumaimeri, 2011). It means reading becomes the important step in developing students mental and linguistic abilities. By learning reading, students will improve their understanding in information and develop their knowledge from the text that they read. Tarigan (2008) in Givanda, (2013) states reading is a process that was done and used by readers to get the author's message. Through reading activity the students can get information, whether general or detail information from a written text. Thus, in order to understand the information in the text, students need to comprehend the text that they have read. 
Comprehension means the process by which a person understanding the meaning of written form or spoken langauge (Alberti, 2014:12) in (Sri Lasmiatun,2016). Snow (2002) also argues that comprehension involves creation of a coherent and integrated understanding of the sentences or paragraphs of the text. It means comprehension is not only about repeating sentences but how the reader integrating all the components in the text likes main idea, supporting detail. By comprehending a text students can understand the text well and get the information of the text. Moreover, reading comprehension is not only a matter of understanding the print on the page, but it is creation of meaning by combining what the print tells and what the reader already possesses as knowledge (Salmi,2011:698) According to Prado and Plourde (2005 in Michele,2013:2) reading comprehension is a process that involves thinking, teaching, past experience and knowledge. By relating students' past experience, knowledge and thinking, the reader will be able to comprehend the text well. In reading comprehension students' ability to grasp the information or idea presented by the author is needed so latter on he or she can interpret ideas of the text (Somadayo et al., 2013:115).

Comprehension become one of the goals that should be achieved in reading because by having a good reading comprehension, students are able to support their carrier, study purpose, positive effect on students' vocabulary knowledge, students are able to spell on their writing and etc. (Rahmawati, Padmawati, \& Ratminingsih, 2014). Considering reading comprehension as an aspect that is very important in learning English, it should be better for the students to practice reading comprehension starting from early age.

Early age is chosen as the best "age" to learn English because the optimum age for children to learn foreign language is when they are still in very young age (Yuliana, 2003:62). The age range of young learners is between 5 years old to 12 years old (Rixon,1999). By seeing the suitable age to start learning English in the age of 5 to 12 years old, then, it is better to introduced English at elementary school.

Teaching English, especially reading, for young learners is not an easy job. In teaching young learners, teacher should have more attention to the appropriateness of teaching strategy. It is because teaching English for young learns in elementary school is different from teaching adult learners. In line with that, Fahmi, Suhartono, \& Arifin (2014) state that young learners have some special characteristic, one of the characters is easy to get bored during the learning process .

Moreover, teaching reading for young learners also can be wonderful adventure for children, if uses an appropriate approach and media in learning process (Paul,203:85). Thus, the teacher must be good in creating a suitable and creative activity in order to build an interesting and joyful situation during the learning process. Besides that, in teaching reading for young learners, the teacher needs attractive and interesting media in order to make them easy to understand the text because the use of interesting and attractive media can make the students enjoy with the learning process and it impact to the effectiveness of the learning process.

Media is one of tools that can help teacher in learning process. The use of media in learning process especially in learning reading for young learners will help the teacher to create a good classroom situation (Sukarno, 2008). By using a good media the teacher can attract students' attention and make the students focus on the learning process. One of the media that can be used by the teacher to teach reading for young learners is story in the form of Big Book.

Story is used to amuse the reader and commonly design in the form of narrative or fiction. In learning process, story is motivating, challenging and fun for young learners. They can help develop positive attitudes towards the foreign language, culture and language learning" (Ellis and Brewster, 1991:1 in Lucie Zigardova, 2006 ). By seeing the benefits story is good to be used in teaching reading for young learners. In fact, still a lot of teacher taught reading by using storybook which sometimes could not attract students' intention. In here, another storybook that can be used in teaching is Big Book.

Big book is described as a large format book with big print texts and illustrations (O'Connor, 2006). The same argumentation states by (Brown, 1980: 315) that big book is a book that has large print and colorful illustrations, that makes the teacher can shared a good stories to the whole classroom. The use of big book in reading activity students can stimulate students' imagination and focus in reading. According to Karges-Bone(1992) in Connor (2006:493), there are several essential characteristics to a successful big book learning experience. Those are, big books are (1) short stories 
(10-15 pages) that immediately engage learners' interest, (2) contain a rhyme pattern that children notice and learn, (3) big book are - big on picturesll which assists in the construction of meaning, (4) have repetitive phrases and a controlled vocabulary that help with vocabulary learning, (5) have a simple, but interesting story line and (6) contain elements of humor (p. 742). The use of big book as a media in teaching helps the students in elementary school to learn English especially in comprehending a reading text. The use of Big Book makes the students happy and motivated them in learning English Mahayanti \& Suantari (2017). Furthermore, the use of big book also could help the teacher to attract students' attention and introduce new vocabulary to the students.

In addition, Nambiar (1991) states that there are several advantages of using big book considering the characteristic of the big book such as, enable the students to see the print of over normal-sized story book, focus the students on specific parts of the text, attract students'attention by the unusual size and facilitate the use of certain reading strategies. Thus, big book is a good media that can be used by the teacher to help the elementary school students in comprehending the reading text.

In implementing big book there are some activities that should be conducted by the teacher in the learning activity (Fisher,1991 cited in Tatminingsih 2013) they are: pre-reading activity, an activity before the reader reading big book and reading the complete story, re-reading activity an activity after reading activity, and close activity. In the pre-reading activity, the teacher shows the front cover, pages, the upper part, and the bottom part of Big Book, the back cover and how to open the book in the right way. By showing the front cover, it will create a conducive to get a great discussion with the learner by giving a comment on the illustration or the picture with the word in the front cover. The teacher tells the title of the book, the writer of the big book, and the illustrator of the big book loudly. Then, they ask about the possible story of the book based on the title and the illustration from the front cover of the book. Then, in reading the complete story, the teacher read the story continuously from the first page until the last page. The teacher read the story loudly along with interesting expressions and intonation. The teacher can stop in certain page and ask the children to guess the text in the next page or give additional information about the story or the illustration. (2) After that, in re-reading activity the teacher repeats the story page by page. The teacher shows the words and says it clearly. The teacher asks the comment from the children about the story and stop for a while in the certain page to give a chance to the children to memorize and guess the next words in the story. Moreover, after reading activity, the teacher discusses the keyword in the story and helping the learner to connect one concept with another concept. Then, the teacher and children read the story together. The teacher gives stressing in the way to read and gives a correction about the way to read in comfortable way.(3) Last, in close activity the teacher gives various types of interesting activities based on the area. The teacher can give guessing word game, bolding the words game, arranging the words game, completing the missing words, coloring picture, drama playing, pantomime, imitating certain character in Big Book, putting number to the picture, storytelling, and many more based on the area.

A study on the use of big book has been conducted by Fahmi, Suhartono, \& Arifin (2014) conducted a study entitled "Improving Students' Reading Comprehension Using Big Book".This research was an action that was done in fifth grade students of SD Negeri 32 Pontianak. The purpose of the research was to help the students to cope with their reading comprehension's problem by using big book. In this study, the researcher focused on the use of big book in descriptive text and the result showed that the students' reading comprehension has been improved after taught by using big book. Furthermore, big book also improve students' attention and participation during reading class activity.

Another research has been done by Mahayanti \& Suantari, (2017) that conducted a research entitled "Developing Big Book as a Media for Teaching English at Sixth Grade Students of Elementary School at SD Laboratotium Undiksha Singaraja". This research was a R \& D (research and development) The subject of this research was thirty-two students of sixth grade students of elementary school. The result of this study showed that, character based big book was categorized as excellent media and it was proper to be used as a media for teaching English at sixth grade students. In addition, the result of questionnaire also showed that students who were taught by using big book were happy and motivated in learning process. They were also said that the use of big book could help them in learning English.

Next, Yuliarsianita (2016) conducted the first study, her researcher developed Big Book as media for students at fourth grade students based on the topics in syllabus. The result of this study showed 
that Big Book developed was categorized as excellent media, but because of the limited time, Big Book produced was only prototype media and has not been implemented in order to know the effectiveness of the Big Book. Thus, in this study, the researcher continued the previous study in order to know the effectiveness of the Big Book.

Moreover, it supported preliminary observation and interview in SD Laboratorium Undiksha Singaraja with the English teacher who taught English for fourth grade students, it was found that media that was used in learning activity was still limited and became one of the obstacles in teaching English. It made the students feel bored and did not give positive response in the learning activity in the classroom.

Similar with the empirical reviews in this study, the researcher also used Big Book as a media in teaching, but in this study there are some differences between those previous researches. This study was experimental study that aimed to investigate whether big book as a media has significant effect or not on students' reading comprehension between experimental group and control group. This study conducted in fourth grade of elementary school students in SD Laboratorium Undiksha Singaraja in academic year 2016/2017.

\section{METHODS}

This study was in the form of Quasi experimental of Posttest Only Control Group Design which purposed to find out whether there was or not any significant effect of the used of Big Book on student's reading comprehension between the experimental group and the control group on students' reading comprehension. The populations of this study were all the fourth grade students of SD Laboratorium Undiksha Singaraja in Academic Year 2016/2017. By using lottery the researcher determined which class belongs to experimental group and which class became the control group. VI A was assigned as the experimental group and VI B was assigned as the control group. In this study the experimental groups treated by using Big Book while the control group treated by using conventional media.

Before distributing the lottery, the researcher done normality and homogeneity test. The result of the normality showed that the two classes had normal distribution and the result homogeneity showed that those two classes were homogeneous.

The variables in this study namely independent and dependent variable. The independent variable of this study is Big Book. Meanwhile, the dependent variable in this study is students' reading comprehension.

In this present study, the instruments that were used to collect the data namely lesson plan and reading comprehension test (posttest). Lesson plan is an important instrument used as a guidance for the teacher in teaching two groups. In this study, there are two different kinds of lesson plans that made by the researcher, they were lesson plan for experimental group and control group. There were 6 lesson plans implemented to both groups. Reading comprehension test (post-test) is a test given at the end of the study to measure students' reading comprehension after the treatments. The reading comprehension test was in form of multiple-choice type test with 40 items. Before the instruments were tried out, the reading comprehension test was consulted with two judges to gain the content validity judgment.

The reading comprehension test was tried out to 26 students at fourth grade students of SDK Karya. . From the empirical validity, it was found that ten items were not valid and those invalid items were dropped. Those items were number 4, 6, 7, 12, 14, 18, 19, 21, 24, and 25. Meanwhile, 30 items was valid, those items were $1,2,3,5,8,9,10,11,13,15,16,17,20,22,23,26,27,28,29,30,31,32$, $33,34,35,36,37,38,39,40$.

Since, the data gained was in form of scores, so it refers to quantitative type of data. It was described by using two types of statistical analysis, namely, descriptive statistical analysis and inferential statistical analysis. In descriptive statistical analysis, the researcher found the mean, median, mode, variance, range, and the standard deviation of the post-test. Meanwhile, in inferential statistical normality testing and hypothesis testing was done by using t-test in SPSS 17.0 Program. 


\section{RESULT AND DISCUSSION}

The data of this study were analyzed using two forms of statistical analysis, namely, descriptive satatistical analysis and inferential statistical analysis. In descriptive statistical analysis was done in order to find out the mean, median, mode, range and standard deviation score of each group. The result of descriptive statistics analysis can be seen in Table 1.

Table 1. Data Distribution

\begin{tabular}{llcc}
\hline No & \multicolumn{1}{c}{$\begin{array}{c}\text { Descriptive Statistics } \\
\text { Analysis }\end{array}$} & Experimental & Control \\
\cline { 3 - 4 } & Mean & 83.56 & 76.19 \\
2 & Median & 83.00 & 77.00 \\
3 & Mode & 83 & 77 \\
4 & Standard Deviation & 8.143 & 7.099 \\
5 & Variance & 66.311 & 50.390 \\
6 & Range & 27 & 30 \\
\hline
\end{tabular}

Based on Table 1 above, the mean score of students in experimental group was 83.56, while the mean score of students in control group was 76.19. Thus from the result above, can be concluded that there is a significance different between experimental and control group from the result of the mean. Meanwhile, the median score of the experimental group was 83.00, while the median score of control group was 77.00. It showed that the middle score of the experimental group was higher than the control group. Moreover, the mode of experimental group in this study was 83 and 77 was the score of the control group. From that result, It could be assumed that the most frequently score appeared in the experimental group was higher than in the control group. Then, the range of the experimental group was 27 while the range of the control group was 30 . In the other side, the variance of the experimental group was 66.311 while the control group was 50.390 . Then, the variance of this study was 66 standard deviation of the experimental group was 9.101 while the standard deviation of the control group was 10.172. Then, the standard deviation of the experimental group was 8.143 while the control group was 7.099. Furthermore, by seeing the result of t-test, the researcher figured out whether or not the implementation of Big Book as media gave a significant effect to students' reading comprehension at fourth grade students.

Table 2: Result of Hypothesis Testing

\begin{tabular}{|c|c|c|c|c|c|c|c|c|c|}
\hline & \multicolumn{2}{|c|}{$\begin{array}{l}\text { Levene's Test } \\
\text { for Equality of } \\
\text { Variances }\end{array}$} & \multicolumn{7}{|c|}{ t-test for Equality of Means } \\
\hline & \multirow[b]{2}{*}{$\mathrm{F}$} & \multirow[b]{2}{*}{ Sig. } & \multirow[b]{2}{*}{$\mathrm{T}$} & \multirow[b]{2}{*}{ Df } & \multirow[b]{2}{*}{$\begin{array}{l}\text { Sig. } \\
(2- \\
\text { tailed) }\end{array}$} & \multirow[b]{2}{*}{$\begin{array}{c}\text { Mean } \\
\text { Difference }\end{array}$} & \multirow[b]{2}{*}{$\begin{array}{c}\text { Std. Error } \\
\text { Differenc } \\
\mathrm{e}\end{array}$} & \multicolumn{2}{|c|}{$\begin{array}{l}95 \% \text { Confidence } \\
\text { Interval of the } \\
\text { Difference }\end{array}$} \\
\hline & & & & & & & & Lower & Upper \\
\hline $\begin{array}{c}\text { Equal } \\
\text { variances } \\
\text { assumed }\end{array}$ & .950 & .333 & $\begin{array}{c}4.08 \\
8\end{array}$ & 70 & .000 & 7.361 & 1.800 & 3.770 & 10.952 \\
\hline $\begin{array}{c}\text { Equal } \\
\text { variances not } \\
\text { assumed }\end{array}$ & & & $\begin{array}{c}4.08 \\
8\end{array}$ & $\begin{array}{c}68.7 \\
21\end{array}$ & .000 & 7.361 & 1.800 & 3.769 & 10.953 \\
\hline
\end{tabular}

Based on the table above, it can be seen that the result of the data shows the significant value of Levene statistic test for equality of variance was .333. It means that the significant value was higher 
than the alpha level $(\alpha=.05)$. Thus, it can be say that there is a significant effect on the use of big book to the students' reading comprehension at fourth grade student in SD Laboratorium Undiksha.

Moreover, the researcher had compared the value of $t$ observed $\left(t_{0}\right)$ and $t$ critical value $\left(t_{c v}\right)$ to determine if the mean score of both group had a significant different. Based on the result in table 4.4, $\mathrm{t}_{\mathrm{obs}}$ was 4.088 at the degree of freedom (df) 50. While, the $\mathrm{t}$ critical value ( $\mathrm{t}_{\mathrm{cv} \text { ) }}$ for degree of freedom (df) 50 was 2.042. Thus, in this study, the comparison between $t_{o}$ and $t_{c v}$ was $4.088>2.042$. It means that the value of $t_{\mathrm{obs}}$ was higher than the value of $\mathrm{t}_{\mathrm{cv}}$. Moreover, from the result above it could be concluded that the alternative hypothesis (Ha) was accepted and null hypothesis (Ho) was rejected. Hence, by considering the result of the data above the research hypothesis of this study is "There is any significant effect of big book as a media on students' reading comprehension at fourth grade of elementary school in SD Laboratorium Undiksha Singaraja in academic year 2016/2017" was accepted.

From the data analysis, in terms of descriptive statistical analysis and inferential statistical analysis, the result showed that the students who were taught by using Big Book as a media for students' reading comprehension had a better achievement rather than the students who were taught by using the conventional media. It can be seen from the result in which the mean score of students in experimental group was higher than the score of students in control group. The mean score achieved by the experimental group was 83.56 , while the mean score for the control group was 76,19 . From, this result it confirm that the experimental group could achieve better rather than the control group $(83.56>76,19)$.

Moreover, concerning the result of inferential statistical analysis, it was found that the value of $t$ observed $\left(t_{o b s}\right)$ was higher that the value of $t$ critical value $\left(t_{c v}\right)$. The result of inferential statistical showed that the value of $\left(t_{\text {obs }}\right)$ was 4.088 at the degree of freedom (df) 50. While, the $t$ critical value $\left(\mathrm{t}_{\mathrm{cv}}\right)$ for degree of freedom (df) 50 was 2.042. Regarding the result of the analysis, in this study the researcher found that the comparison between $t_{\mathrm{obs}}$ and $\mathrm{t}_{\mathrm{cv}}$ was $4.088>2.042$. Moreover, the result of inferential statistic analysis also found that the value of Sig. (2-tailed) was) .000 which was less than the standard alpha level $(\alpha=0.05)$. Considering the finding in this study, it is proven that the used of Big Book as a media is effective to help students performed better in reading comprehension rather than the used of conventional media in reading comprehension. In the other words, after being analyzed descriptively and inferentially, the students in experimental group achieved better result than the students in control group.

In this study, both experimental group and control group were given treatments by the researcher. In here, the researcher conducted six times for each group. The experimental group was taught by using Big Book. In giving the treatments the researcher used three Big Books in which have a different theme, they were color and shape, part of body and jobs. The first big book entitled The Journey of Little One, the second book entitled The Story of White Spotted and the last big book entitled Find Me! which has theme about color and shape. In implementing the big book for the experimental group, the researcher were done some activity in the learning process as states by Fisher (1991) in (Tatminingsih, 2013): they were pre-reading activity, re-reading activity and close activity. Pre-reading activity was an activity before the reader reading big book and reading the complete story then, re-reading activity was an activity after reading activity, and close activity was the last activity in which the teacher gives various types of interesting activities in this phase.

Before showing the big book to the students, the teacher asked the students to make "U" shape in front of the teacher. After that, the teacher started the pre-reading activity. In pre-reading activity the teacher showed the book to the students and invited the students to look at the front and the back cover of the book and how to open the book in the right way. By showing the front cover, it would create a conducive situation to get a great discussion with the learner by giving a comment on the illustration or the picture with the word in the front cover. It also states in O'Connor, (2006) where the teacher asked the learners to look the cover illustration of the book and asks, "What do you see?", it aims to create a good discussion with the students. Then, the teacher also introduced the title of the book, the writer of the big book, and the illustrator of the big book loudly. After that, the teacher were asked the students about the possible story of the book based on the title and the illustration from the front cover of the book like "What do you think will happen in this book?" This activity can help the students in constructing the meaning of the story through the illustration of the book. 
Then, in reading the complete story, the teacher read the story continuously from the first page until the last page. The teacher read the story loudly along with interesting expressions and intonation. Throughout, the interesting expression and intonations the teacher could attract students enthusiastic in learning the story. Sometimes, the teacher also can stop in certain page and ask the children to guess the text in the next page. It was done in order to check the students understanding about the story. Meanwhile, when the students could not understand the story, teacher also gives additional information about the story or the illustration in order to help the students to understand it.

After that, in re-reading activity the teacher repeated the story page by page. The teacher showed the words and says it clearly. While reading the story the teacher also showed the picture and run a hand or a pointer under the text the learners hear. This activity was done in order to help the students where there were some difficult word that the students did not understand or the word that the students did not know how to pronounce it correctly. After that, the teacher ask the students to express their own interpretation of the story by asked the comment from the students about the story and stop for a while in the certain page to give a chance to the children to memorize and guess the next words in the story. The students also needed to answer some questions related with the story given by the teacher. That was done in order to check the students' comprehension about the text itself. That is why rereading activity was an important process to help students in comprehension, it is because repeating readings of the same texts in a feature of shared reading, have been shown to be very effective in developing L1 fluency that impact to the comprehension of the students (Samuels, 1997 in Connor, 2006),

Moreover, after reading activity, the teacher discussed the keyword in the story and helping the learner to connect one concept with another concept. It was done by relating the students experience to the meaning of the story as well as their own language to the text indicated comprehension both the story and the function of the text. Then, the researcher read the story together with the students and while reading the teacher would give stressing in the way to read and gives a correction about the way to read in comfortable way. Through shared reading the students were able to see the text and they also could discuss the story with their friends. In addition, while reading the teacher will stop and invited the students to read along or "chime in" when there are repeated words, phrase or dialogue (O'Connor, 2006).

Last, in closing activity the teacher invited the students to join an activity. In this step the teacher provided the students with various types of interesting activities. The teacher gave guessing word game, bolding the words game, arranging the words game, completing the missing words, coloring picture, drama playing, imitating certain character in Big Book, putting number to the picture, storytelling, and many more based on the area. In this activity the teacher (the researcher) used "stick it" game where in this games the students were needed to stick some pictures in the white board based on the right sequence related to the story. Then, the teacher also conducted a game by using "cloze text" so in here the students were asked to fill the missing words of the text by stick the words on the text that already provided by the teacher and the last by using game called "pick me" where in this game the students were asked to pick one ice cream stick that already consist of number 1 to 20 . Then, the students needed to answer the question that related to the story based on the number that they took. In the last activity the students were very happy and enthusiastic in followed the learning process. The used of the various games or activities was very helpful for making the lesson more interesting, lively and fun since we know that children have a short attention in learning that made them easy to uninterested in following the learning process (Sukarno, 2008).

Considering the result of the study above, it can be states that the implementation of Big Book as a media in teaching reading comprehension on the fourth grade students brought a better achievement to the students than the conventional media. Through the implementation of big book, there were some advantages the students got such as, Big book could increase students motivation in learning. In here the used of big book as media in teaching reading comprehension made the students more motivated in reading because of the appearance of big book that interesting and has unusual size for the students. In line with this Dahl (2001: 43) in (Fahmi et al., 2014), states that one of the most effective ways to get young children involved with print is through the use of shared reading of enlarged texts. Through the enlarge text, the teacher allow all the students in the classroom to see and react to the words. Supported the argumentation above, Suyanto (2007:104) in (Fitriani, Ika, Cahyono, 1997) also states 
that due the unusual size from ordinary book, big book can be seen easily from all part of the class that make students would pay attention to the story started from the beginning until the end. In addition, through big book students also feel more enjoy in reading because of the good quality of the big book itself (Harun \& Rahim, 2010). Harun \& Rahim, (2010) also states that by using big book the students were respond all the questions that given by the teacher well. It meant the students are really enthusiastic and motivated to follow the learning activity.

Big Book helps the teaching and the learning process in the classroom more alive and pleasant because the use of big book is effective for the young learners. The students actively follow the activity starting from the beginning until the end of the activity. Young learners are the learners that have limitation in knowledge Brendon,(2012) in Djalal, (2017:204), since big book consists of the colorful illustrations the students are so actively asked some questions that are related with the story and about some difficult words that they found from the big book. They are also enthusiastic in answered the questions that given by the teacher related to te story. In line with this statement, (Fahmi et al., 2014) states that one of the benefits of Big Book was to increased students' participations in reading class activity.

Big Book attracts students' attention because big book is media that unique and new thing, that the students have not known before (Fitriani, Ika, Cahyono, 1997). Unusual characteristic and the colorful illustration also become ones of the attractions of big book. Young learners as the subjects of this study had a short attention span that made them easier to get bored in learning process. Thus, big book was a good media that could eliminate the students' short attention by seeing the colorful illustration of the story.

Big book helped the students to construct the meaning of the text and lead them have deeper understanding of the text given. Media is one of the points that have to be considered by the teacher in teaching English for young learners (Sukarno, 2008), by using an appropriate media, the teacher is be able to create a better classroom situation and it also help the students to construct the meaning of the text and leads them to the deeper understanding of the text. This statement is supported by KargeBone, (1992) in O' Connor, 006) argue that big book can help the students to construct the meaning of the text and lead them to the deeper understanding of the text.

Overall, based on the discussion of the findings described above, it can be inferred that Big Book as media can be effective to be implemented in teaching reading for students in elementary school especially at fourth grade students in SD Laboratorium Undiksha in academic year 2016/2017. It was also proven by the result of the descriptive and inferential analysis which showed the result of t-test and mean score of experimental group was higher that the control group.

The result of this study is supported by the previous study conducted by Fahmi et al., (2014) that was done in fifth grade students of SD Negeri 32 Pontianak. The result of the study showed that the students' reading comprehension has been improved after being taught by using big book. Furthermore, they also found that big book also improved students' attention and participation during reading class activity. Another, previous study that also supported this study was conducted by Tatminingsih (2013) that focuses on the use of the big book as a learning model. The study was conducted at Ananda Kindergarten. She proved that the activity of learning through the use of big book could improve the readiness of children to read. It is also supported by the result of calculation of the t-test, that showed there was a significant different ( $\mathrm{p}$-value $<1 \%$ ) amounting to 0.0348 . In addition, the previous study by (Harun, Rahim, 2010) that was done in two classroom of primary school in rural area in Malaysia.

\section{CONCLUSION}

The result of the findings, showed that there was a significant effect of Big Book as a media in students' reading comprehension at fourth grade students at SD Laboratorium Undiksha Singaraja. It was proven through the result of the post-test of experimental and control group which were analyzed descriptively and inferentially. The result showed that the mean score of experimental group was higher compared with the score of control group. The mean score of the experimental group was 83.56 while the score of control group was 76.19.

Besides that, the result of the inferential statistical showed that the null hypothesis of the study was rejected while the alternative hypothesis was accepted. It happened because the value of t- 
observed $\left(t_{\text {obs }}\right)$ was higher than the value of $t$-critical value $\left(t_{c v}\right)(4.088>2.042)$. Therefore, the result above indicates that the use of Big Book as a media in teaching reading at fourth grade students gave a significant effect rather than the use of conventional media as a teaching media.

Based on the conclusion of this study, there are some suggestions that can be made. First suggestion specifically, was addressed to English teachers because it was found that Big Book as media affects better than conventional media on the sixth grade students of SD Laboratorium Undiksha Singaraja, so the English teacher should take this finding as a consideration when they teach reading to the students. It has been proven empirically that this media is effective to be used to improve students' reading comprehension. Second suggestion is for other researchers who are interested to conduct similar research, it is suggested that the same study can be conducted but in the different grade. Besides that, the other researchers are also suggested to observe more about the other benefits of big book on students' reading comprehension.

\section{REFERENCES}

Alshumaimeri, Y. (2011). The effects of reading method on the comprehension performance of Saudi EFL students, 4(1), 185-195.

Brown, E. The bases of reading acquisition. Reading Research Quarterly, 1970, 6, 49-74

Connor, O. (2006). Using Big Books : A Standards-Based Instructional Approach for Foreign Language Teacher Candidates in a PreK - 12 Program, 39(3), 487-506.

Djalal, S. A. (2017). The Advantages Of Teaching English To Young Learners By Using Obot Game Song. The 2nd Teylin International Conference, (April), 201-206.

Fahmi, D. I., Suhartono, L., \& Arifin, Z. (2014). Improving students' reading comprehension using big book, $1-11$.

Fitriani, Ika, Cahyono, B. Y. (1997). The Effectiveness Of Implementing Big-Book And NarrativeScaffold On The Students' Achievement In Writing Narrative Texts, 1-13.

Harun, Rahim, N. A. (2010). Students 'Perception Towards The Usage of the Big Book. Gadiing Business and Management, 14(2003), 48-54.

Lasmiatun,Sri (2016). The Implementation of Story Grammar Strategy in Teaching Narrative Test for VIII Grade Students at MTs Al Ma'Arif Tuluangagung.

Mahayanti, N. W. S., \& Suantari, N. L. P. M. (2017). Developing Big Book as a Media for Teaching English at Sixth Grade Students of Elementary School at SD Lab Undiksha Singaraja. . Journal of Education Research and Evaluation. Vol., 1(2017), 128-136.

Michele, H. (2013). Reading Comprehension : Strategies for Elementary and Secondary School Students Michele Harvey 225 Farmdale Drive Madison Heights, VA 24572 Lynchburg College, 2-17.

Nambiar, M. (1991). Big books for little read- ers: Works in the ESL classroom too. (Eric Document Reproduction Service No. ED 333 736).

Paul, David. (2003). Teaching Englishto Children in Asia. Hong Kong: Pearson Education Asia Ltd.

Rahmawati, L., Padmawati, N., \& Ratminingsih, M. (2014). The Effect Of Circ Strategy And Achievement Motivation Toward Students ' Reading Comprehension. E-Journal Program Pascasarjana Universitas Pendidikan Ganesha, 3(1980), 1-12.

Salmi, M. Al. (2011). S Chemata ( Background Knowledge ) And By By. Research Journal Specific Education, (22), 696-708.

Snow, C. (2002). Reading for Understanding Toward an $R \&$ D Program in Reading Comprehension. Office of Educational Research and Improvement. Retrieved from http://www.rand.org/publications/MR/MR1465/ 
Somadayo, S., Nurkamto, J., \& Suwandi, S. (2013). The Effect of Learning Model Drta ( Directed Reading Thingking Activity ) Toward Students ' Reading Comprehension Ability Seeing from Their Reading Interest, 4(8), 115-123.

Sukarno. (2008). Teaching English To Young Learners And Factors To Consider In Designing The Materials Oleh: Sukarno (Faculty of Languages and Arts Yogyakarta State University), $57-73$.

Suyanto, K.K. E. 2007. English for Young Learners. Jakarta: Bumi Aksara.

Tatminingsih, S. (2013). International Conference On Educational Research and Innovation. In Big Book, A Teaching Alternative For Improving Children's Reading Readiness In Kindergarten. Yogyakarta: UNY Press.

Tatminingsih, S. R. I. (2013). Big Book, A Teaching Alternative For Improving Children ' S Reading Readiness In, 1-12.

Yuliana. (2003). Teaching English to Young Learners through Songs, 5(1), 62-66.

Yuliarsianita,K.A.M. (2016). Developing Character Based Big Book As Media For,1-131 